\section{(C) OPEN ACCESS}

\title{
Asymptomatic dysphagia causing recurrent aspiration pneumonia
}

\author{
Anders Løkke, ${ }^{1}$ Lycely Calderon Dongo, ${ }^{1}$ Karin Bak Aksglæde, ${ }^{2}$ Ole Hilberg ${ }^{3}$
}

Department of Respiratory Medicine and Allergy, Aarhus University Hospital, Aarhus, Denmark

${ }^{2}$ Department of Surgical Gastroenterology, Aarhus University Hospital, Aarhus, Denmark

${ }^{3}$ Department of Pulmonary Medicine, Sygehus Lillebalt Vejle Sygehus, Vejle, Denmark

Correspondence to

Anders Løkke,

aloekke@gmail.com

Accepted 20 July 2018

\section{Check for updates}

(c) BMJ Publishing Group Limited 2018. Re-use permitted under CC BY-NC. No commercial re-use. See rights and permissions. Published by BMJ.

To cite: Løkke A, Dongo LC, Aksglæde KB, et al. BMJ Case Rep Published Online First: [please include Day Month Year]. doi:10.1136/bcr-2018 224370

\section{SUMMARY}

52-year-old male patient with known bipolar disorder and innate cerebral palsy causing widespread spasticity problems. Treated for 2 years with antidepressants and electroconvulsive therapy. He repeatedly presented with - and was treated for-pneumonia resulting in more than 20 episodes of hospital admission. He underwent numerous examinations until a diagnosis of dysphagia was established using video fluoroscopic swallowing examination (modified barium swallow). Eventually, as all other treatment regimens had proven effortless, percutaneous gastrostomy feeding tube was inserted and intensive training with a specialised occupational therapist was started. This treatment regimen caused the recurrent episodes of pneumonia to vanish. It is important to acknowledge that otherwise silent dysphagia may cause recurrent pneumonia.

\section{BACKGROUND}

Pneumonia is a very common condition that most doctors face frequently, and normally it is rather easy to treat. However, when a patient presents with recurrent pneumonia, it is time to pause and consider why-including age and expositions into considerations.

It is important to note that in many cases, swallowing disorders may occur in the absence of symptomatic dysphagia. Silent aspiration may occur when the patient is unaware and there are no signs of obstruction such as coughing. As a result, aspiration is often overlooked and silent dysphagia may cause recurrent pneumonia.

\section{CASE PRESENTATION}

A 52-year-old man with known congenital cerebral palsy causing widespread spasticity problems, swallowing dysfunction and bipolar affective mental disorder. He was treated with phenytoin, carbamazepine and baclofen.

Due to personality and behavioural disorder, depressive traits and self-harm, the patient was admitted to the psychiatric department 15 times in 2012 and 14 times in 2013 and was treated with electroconvulsive therapy (ECT) 12 times in 2013.

In 2014, he had 22 contacts to the emergency department due to pneumonia.

Suspected asthma led to treatment with inhalation medication without effect.

Immunodeficiency disorder was ruled out.
Bronchoscopy was macroscopically normal, negative microbiological growth.

Walking test and lung function test were normal.

Referred to occupational therapist in February 2015 for swallowing test without signs of dysfunction. However, strength, muscle tone and coordination of the tongue were found to be reduced. A video fluoroscopic swallowing examination (VFSE), also called modified barium swallow, in April 2015 showed 'profound tendency of retention in vallecula and silent aspiration'.

A nasogastric feeding tube was placed tentatively, resolving the recurrent episodes of pneumonia immediately. In August 2015, a percutaneous gastrostomy feeding tube was placed and intensive training with a specialised occupational therapist was initiated-primarily involving training of the swallowing function, the strength of the muscles in the tongue and the throat as well as paying much attention when drinking and eating. The patient started off with nothing per os for a month, followed by very slow introduction of fluid and solid food over a course of several months (case time course shown in table 1).

\section{INVESTIGATIONS}

- Otorhinolaryngologist, flexible laryngoscopy.

- Neurological evaluation.

- Psychiatric medicine adjustment, electroconvulsive therapy.

- Respiratory physician evaluation.

- Immunodeficiency evaluation, HIV test.

- Bronchoscopy.

- High-resolution CT.

- Six-minute walking test.

- Lung function test.

- Specialised occupational therapist evaluation.

- VFSE $\times 3$.

\section{DIFFERENTIAL DIAGNOSIS}

- Tracheo-oesophageal and tracheopulmonary fistulas.

- Foreign bodies.

- Infections.

- Obliterative bronchiolitis.

\section{TREATMENT}

Multidisciplinary teamwork:

- Specialised occupational therapist.

- Gastroenterology surgeon.

- Respiratory physician. 


\begin{tabular}{llll}
\hline Table 1 & \multicolumn{1}{l}{ Schematic overview of the case time course } \\
\hline 2014 & 2015 & 2016 & 2017 \\
\hline $\begin{array}{l}22 \text { admissions } \\
\text { due to } \\
\text { pneumonia }\end{array}$ & $\begin{array}{l}\text { April:VFSE shows } \\
\text { retention and silent } \\
\text { aspiration }\end{array}$ & $\begin{array}{l}\text { May: removal of } \\
\text { feeding tube }\end{array}$ & $\begin{array}{l}\text { September: VFSE } \\
\text { without change }\end{array}$ \\
& $\begin{array}{l}\text { August: insertion of } \\
\text { gastrostomy feeding tube }\end{array}$ & $\begin{array}{l}\text { No new episodes } \\
\text { of pneumonia for } \\
\text { several months }\end{array}$ \\
& $\begin{array}{l}\text { August-May: intensive } \\
\text { training with speech } \\
\text { therapist }\end{array}$ & \\
& VFSE without change & \\
\hline
\end{tabular}

VFSE, video fluoroscopic swallowing examination.

\section{OUTCOME AND FOLLOW-UP}

After 9 months of treatment without pneumonia, the gastrostomy tube was removed. No incidence of pneumonia occurred in the 6 months following removal.

VFSE control in September 2017 showed unchanged profound tendency of retention and silent aspiration.

\section{DISCUSSION}

In the case presented, a patient with numerous predisposing conditions-such as cerebral palsy ${ }^{12}$ with related behavioural, emotional and psychiatric disorders ${ }^{34}$ as well as gastrointestinal symptoms ${ }^{5-7}$ and treatment with neuropsychiatric medication ${ }^{8-11}$ — was admitted repeatedly due to pneumonia and underwent numerous examinations. Because of silent aspiration, the possibility of a swallowing disorder was not pursued until rather late in the course.

Numerous solutions were tried, including sleeping with the head elevated, reduction in the neuropsychiatric medication as well as prophylactic antibiotics with azithromycin.

The final treatment solution with a gastrostomy tube and the intense occupational therapist training may seem rather drastic, but the time course, the number and severity of the pneumonia episodes as well as the deterioration of the patient's mental state resulting in admission due to depression and even ECT treatment should be included in the considerations. Indeed, silent aspiration can be missed-especially in a patient with cerebral palsy. The result can be devastating as well as life-threatening.

\section{Patient's perspective}

I had a very rough time accepting the feeding tube and the fact that I was not allowed to eat or drink for several weeks. On the other hand, the recurrent pneumonia and hospitalisations made my life miserable: I was physically weakened, had poor quality of life and was admitted several times due to depression caused by my situation.

After re-introduction of food, my mood improved as well as my physical shape... in the end I got my life back!

\section{Learning points}

Aspiration in patients with recurrent episodes of pneumonia should be considered.

- Numerous conditions can lead to aspiration, including a variety of different medications.

- Aspiration can be silent and thus easily overlooked.

- Silent aspiration can be devastating as well as life-threatening.

- A rather simple solution such as a feeding tube should not be ignored and should be considered early on as a treatment solution in relevant patients.

- Specialist training by an occupational therapist of the swallowing function and the muscle strength in the tongue and throat can be pivotal.

Contributors LCD contributed to writing and discussion. KBA contributed to writing and discussion. $\mathrm{OH}$ contributed to planning, writing and discussion. AL contributed to planning, writing and discussion.

Funding The authors have not declared a specific grant for this research from any funding agency in the public, commercial or not-for-profit sectors.

Competing interests None declared.

Patient consent Obtained.

Provenance and peer review Not commissioned; externally peer reviewed.

Open access This is an open access article distributed in accordance with the Creative Commons Attribution Non Commercial (CC BY-NC 4.0) license, which permits others to distribute, remix, adapt, build upon this work non-commercially, and license their derivative works on different terms, provided the original work is properly cited and the use is non-commercial. See: http://creativecommons.org/ licenses/by-nc/4.0/

\section{REFERENCES}

1 Rosenbloom L. Definition and classification of cerebral palsy. Definition, classification, and the clinician. Dev Med Child Neurol Suppl 2007;109:43.

2 Rosenbaum P, Paneth N, Leviton A, et al. A report: the definition and classification of cerebral palsy April 2006. Dev Med Child Neurol Supp/ 2007;109:8

3 Bjorgaas HM, Hysing M, Elgen I. Psychiatric disorders among children with cerebral palsy at school starting age. Res Dev Disabil 2012;33:1287-93.

4 Gabis LV, Tsubary NM, Leon 0, et al. Assessment of abilities and comorbidities in children with cerebral palsy. J Child Neurol 2015;30:1640-5.

5 Del Giudice E, Staiano A, Capano G, et al. Gastrointestinal manifestations in children with cerebral palsy. Brain Dev 1999;21:307-11.

6 Erasmus CE, van Hulst K, Rotteveel JJ, et al. Clinical practice: swallowing problems in cerebral palsy. Eur J Pediatr 2012;171:409

7 Erkin G, Culha C, Ozel S, et al. Feeding and gastrointestinal problems in children with cerebral palsy. Int J Rehabil Res 2010;33:218-24.

8 Carl LC. Drugs and dysphagia: how medications can affect eating and swallowing: I Pro Ed, Inc., Austin, 2006.

9 Balzer KM. Drug-induced dysphagia. Int J MS Care 2000;2:40-50.

10 Heckel M, Stiel S, Ostgathe C. Smell and taste in palliative care: a systematic analysis of literature. Eur Arch Otorhinolaryngol 2015;272:279-88.

11 Rudolph JL, Gardner KF, Gramigna GD, et al. Antipsychotics and oropharyngeal dysphagia in hospitalized older patients. J Clin Psychopharmacol 2008:28:532-5. 
Copyright 2018 BMJ Publishing Group. All rights reserved. For permission to reuse any of this content visit http://group.bmj.com/group/rights-licensing/permissions.

BMJ Case Report Fellows may re-use this article for personal use and teaching without any further permission.

Become a Fellow of BMJ Case Reports today and you can:

- Submit as many cases as you like

- Enjoy fast sympathetic peer review and rapid publication of accepted articles

Access all the published articles

- Re-use any of the published material for personal use and teaching without further permission

For information on Institutional Fellowships contact consortiasales@bmjgroup.com

Visit casereports.bmj.com for more articles like this and to become a Fellow 